\title{
Effect of Exercise Tube Kick on Skill Master Style Students of Jambi University
}

\author{
Ilham \\ University of Jambi \\ Jambi, Indonesia \\ zuhri.saputra.hutabarat@gmail.com
}

\author{
Zuhri Saputra Hutabarat \\ University of Jambi \\ Jambi, Indonesia \\ zuhri.saputra.hutabarat@gmail.com
}

\begin{abstract}
This research can be done to know the effect of kicking tube training to lifestyle of FIK students of Jambi University Sport Science Training Program class of 2015/2016 class A. Its benefits are: 1) for swimming trainers is, in order to be used as a basis in the athletes training to improve swimming skills breaststroke 2) For lecturers and teachers is, in order to be used as a reference in teaching students or their students in improving swimming skills. 3) for academics or scientists is, in order that the results of this study can be used as reference materials and insight special scholars swimming breaststroke. 4) for athletes swimming pools are expected to train themselves by using tube kick exercises to improve speed and train them in chest pool exercises. This research is a research using One Pretest-Posttest Design. The variables of this research consist of the free variable that is Tube Kick Exercise and variable that is skill force that is Chest. This research tool uses style pool test while doing observation using observation sheet with a keyword which according to what is done by the sample with what is listed on observation sheet, which based on suit what is done by the sample with that in observation sheet. Test the observations that have been done trials to see the validity and reliability. The collected data were analyzed by using a t-test but previously tested normality and homogeneity. Based on the results of the hypothesis obtained thing $=2.867>$ table $=1.98$, meaning the research hypothesis that said there is the influence of tube kicking exercises against the swimming force of students FIK UNJA Prodi Coaching Sports force 2015/2016 class A accepted. The conclusion of this research that there is the influence of tube kick exercise to the introduction of breast force of student of FIK UNJA Prodi coaching of sports class of 2015/2016 class A.
\end{abstract}

Keywords-Kick, Skill, Swimming Chest style

\section{INTRODUCTION}

Swimming is a very good sport against body growth because with swimming all members of the body can move freely from the feet, hands to the head. Swimming sport is one of the achievement sports that must be contested at every multi-sport event, therefore the sport of swimming pool need to be disseminated in the community evenly. To popularize the sport of swimming is the path that is considered appropriate is through the school education path, starting from primary education to college.
To be able to swim skillfully but supported by good physical condition also needed some basic swimming technique which must be mastered by swimmers such as body position in the water, arm movement, leg movement, breathtaking, and coordination movement and the last one is star technique.

In studying the first breaststroke pool we have to shape is a basic skill based on the motion mechanics of the swim style, meaning that the chest swimmer must have its own type or style according to the motion style mechanics that exist in the chest pool. Likewise, in the implementation of the exercise should pay attention to the principle of specificity, especially on certain physical parts that can support the swimmer's skills. As explained by [1], a swimmer that in training the breaststroke force to pay more attention to the movement of the limbs because the role of the limb is more dominant than arm movement.

According to [2] say that in order to gain great boost strength and good breaststroke techniques, leg muscle strength must be trained with weights, one form of leg muscle strength training that is very well done is by do tube kick exercises, for that in the research done tube kick exercises while exercising chest pound swimming motion movements, with a view to improve chest-style swimming skills.

Based on the above description can be formulated problems as follows whether there is the influence of tube kick exercises on the skill of breaststroke swimming students FIK University Jambi Sports Science Training Program force 2015/2016.

\section{A. Chest Pool Skills}

Swimming breaststroke is a pool that focuses the technique on foot movement, because of the movement of the foot that many moves to encourage acceleration while handing movement only a little help acceleration on the breaststroke pool.

Ref [3] says that chest-pool skills are more generated by leg movements than arm movements. This is because the thrust generated by the movement of the limbs for the future glide is greater when compared to the impulse generated from the pull of the arm. 
According to [4] skill, swimming breaststroke is the ability of a person to do swimming style of the chest with good basic techniques as well as coordinated smoothly, precisely and quickly.

From the understanding of chest-style swimming skills above can be concluded that the chest-style swimming skills are the ability to do the combination of leg movement and pull the arm properly and correctly and quickly to provide the impetus to the fore followed by proper breathing techniques. The following describes some of the things related to cheststyle swimming skills, among others:

\section{B. Swimming Chest Style}

Swimming is an activity passing over the water surface by using limb movements. The breaststroke pool is the style first learned by most people as they begin to learn to swim. The breaststroke pool is the most effective force used for longrange swing, as Captain Webb did when crossing the strait [5].

Pool chest is a pool that is done from the start to the finish position of the body remains facedown, the position is maintained while doing a pulling movement with the position of both hands straightforward, the two backs of each other hand and each palm facing out while doing a pull, extend like positive above repeatedly, hand movements are always at the same time and followed by the encouragement of the limb chair by kicking, pulling, kicking, pulling so on, the movement of both limbs is done simultaneously in a horizontal position. Each one circuit is a one-time push off the leg and one straight-handed pull is taken, the head is slightly visible above the surface of the water and breaks the surface of the water [6].

Swimming breaststroke or frog style is swimming with the chest position facing the water surface, but different from the freestyle, the torso is always in a fixed state. Both legs kick outwards while both hands are straightened forward. Both hands are opened to the side like a movement splitting water so that the body forward faster ahead. Body movements mimic the movement of frogs are swimming so-called frog style. Breathing is done when the mouth is on the surface of the water, after a single hand-foot movement or two-handed foot movements [7].

Based on the above understanding it can be concluded that the breaststroke pool is an activity passing over the surface of the water with the position of the body from the star until the finish is done with the position of the body facedown while the arms do dance movements with the palm of the hand facing out as both legs do the movement push with the way the two legs kick, pull repeatedly and simultaneously.

\section{Basic Techniques for Chest Pool}

According to [5], the basic techniques of chest pool movement consist of body position, foot movement, arm movement, foot movement coordination with arm and breathing, star movement and finish. Based on the above opinion it can be summarized that the basic techniques of chest pool movement include:

\section{1) Body position}

The body pose on the chest pool equals the body position in the other pool style ie the average water. This position occurs after the swimmer star then glide straight his arms forward to the side of the ear, chin inserted into the neck so that the head slightly above the water surface and the body float in the water.

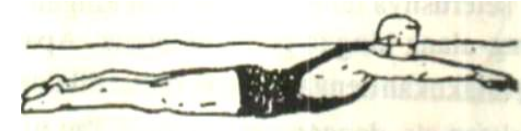

Fig 1. Body position in swimming chest style [8]

\section{2) Foot movement}

Starting motion: Standing in a pool pond, the body facing the edge of the pool, both hands clinging to the edge of the pool. Then lift the body and both feet up to the water surface, until the body and both legs Larus are above the water surface.

Movement Process: Pull both knees sideways somewhat obliquely downward, both heels tightly. Heels are released, both legs wide open to the side. Then with a strong movement immediately the two legs are tightened back until the state of the body and both legs straight back like the original attitude. When pressed both legs trying to keep the ankle weak. After both legs are tightly backward, immediately the knees pull back to the side, the heels meet tightly. Both heels are released both legs opened to the side width, and soon both feet tightened again. So the movement goes on and does over and over until the movement really can be done well and correctly.
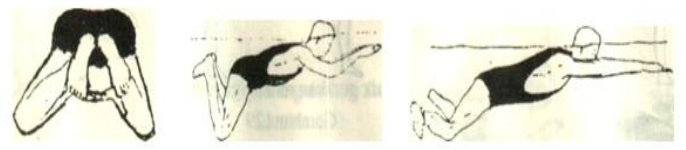

Fig 2. Foot position in swimming chest style [8]

\section{3) Hand movement}

Beginning Movement: Standing in the pool, both legs opened, body bent over the water surface. Both hands are straightforward, palms facing down, fingers clasped together, and face facing into the water.

Movement Process: While pressing the water, both hands pull sideways somewhat obliquely down, palms facing sideways with fingers fixed tightly, and the elbows remain straight. Both hands are located under the shoulders. as quickly as possible the two elbows are bent or folded until both hands are under the chest and the palms are facing downward, keep pushing again straight ahead. And so on, both hands are moved from front to side sloping downwards, then both elbows folded, and both hands push forward straight ahead, this movement is done repeatedly until it can be mastered well and smoothly. When pulling both hands sideways downward, the head is lifted or the face is lifted up to the surface of the water (to take a breather) and straight time again both hands forward face inserted into the water (breath expelled in water). 


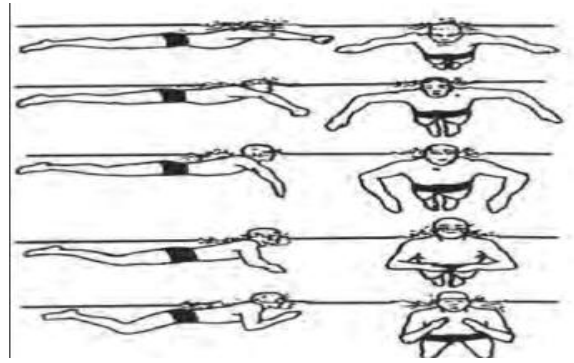

Fig 3. Hand movement in swimming chest style [9]

4) Coordination of hand and foot movements as well as breathing perception

How to perform motion coordination are movements of the hands and feet as well as breathing, as follows:

Beginning Attitudes: Same on glide exercises, (body position of breaststroke pool in water)

Movement: Prepare the foot on the pool wall as hard as possible until the body slid straight ahead over the water surface. As the body slides over the water, the knees are pulled sideways slightly obliquely downward, the heels tight. Both hands are pulled sideways to the underside of the head lifted (to take a breather), by the time the two elbows are folded under the chest, both heels are released until both legs open sideways. Then, simultaneously pushing hands straight forward, the head or face enter again into the water (the breath is removed), the legs immediately pushed together until the straight body (including both hands and two legs) straight is a straight line. It should be noted that the motion is closing both legs that move like whip or whip.

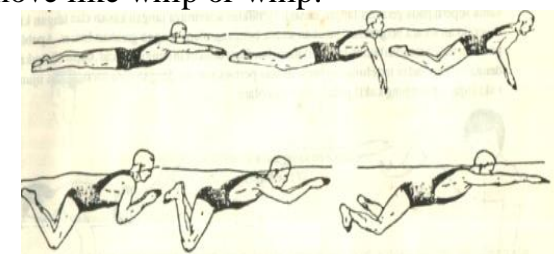

Fig 4. Coordination movements in swimming chest style [8]

\section{5) Star movement}

Star used in chest pool is done on the star beam by jumping, star sequence on breaststroke include: a) As the referee blows the long whistle, the swimmer steps up the top of the star beam and stays on top, both fingertips are attached to the star beam lips. b) do the stooping with both arms straight while holding on to the lips of the star, straight ahead, c) In subsequent period the swimmer releases the grip while bending his body close to the water with his arm gestured backward by swinging the arm moving forward so that the body moves forward, with the impulse of the swing body leaning the water surface, the body posture that will fall assisted the pedestal of the sole of the foot leaping star beams and bodies start to take off. d) When the body is floating arms and legs are cultivated with a straight attitude when entering the water surface.

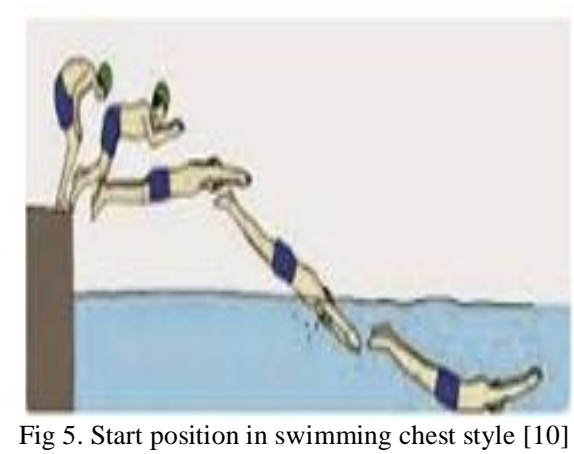

\section{6) Reversal}

For a chest pool reversal movement just like any other swimmer, the swimmer must touch the pool wall before making a reversal. As for the rules of chest pool reversal as follows:

a) When the swimmer arrives at the reversal wall both arms are straightened together until both hands touch the wall. b) After both palms touch the wall, one hand is released and then pulled sideways while twisting the body until both feet touch the wall while bending both knees simultaneously and both arms in front of the chest. c) Further straightening the two forearms through the foot pedestals do the impulse to leave the wall, after leaving the wall swimmer to move the arm and leg once newly allowed out take a breath to do swimming. For details see the following picture based on the arrow.

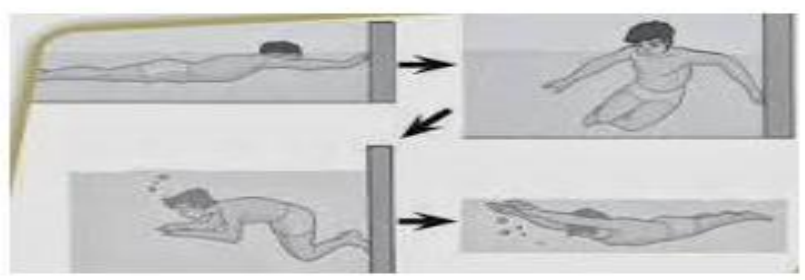

Fig 6. Reverse position in swimming chest style [10]

\section{7) Finish}

While the swimmer's swimming swimmer's motion is to swim around the pool with both palms simultaneously, this movement is the same as the finish motion of the butterfly pool (see figure 7), while for the freestyle pool and the backstroke can touch the finish with one hand.

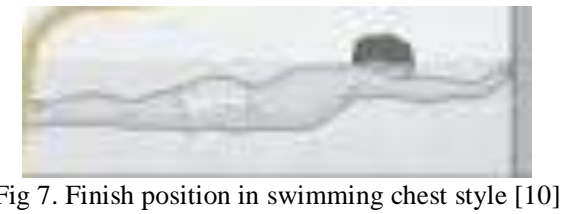

\section{Exercise tube kick}

Tube kick exercise is basically a form of exercise performed to form leg muscle strength in general, but the tube kick exercise is done to improve the ability of leg muscles of swimmers with the intention that swimmers have the skills and speed of swimming in general. Speed and skill of breaststroke are strongly influenced by leg muscle ability, hence in this 
research is done tube kick exercises to improve skill swimming pool of students coaching sports.

Tube kick exercises are exercises done to increase the power of the foot, by tying the rubber around the waist and pulling by doing the foot movements as hard as possible. The following forms of tube kick exercise done in this study in order to improve the chest-style swimming skills.

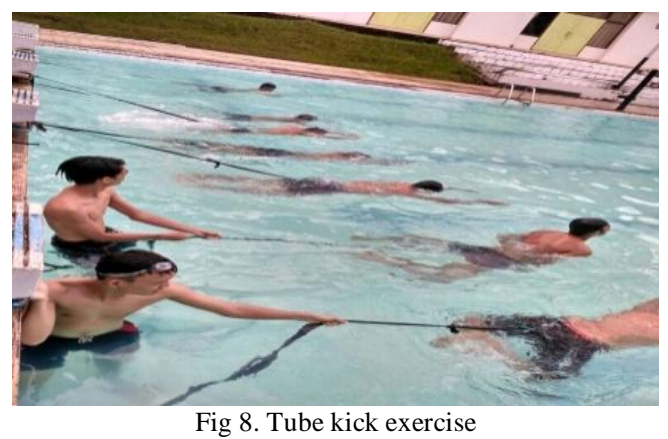

Tube kick exercise is a form of exercise Increased leg power, by tying the rubber tip on the waist while the other end is tied at the edge of the pool or held by another friend then the swimmer pulls by doing the movement of the breast force in place as hard as possible in the water continuously, while both arms are straightforward swim in a stationary position, this tube kick exercise is commonly used for swimmer breaststroke, since pool style is largely determined by the ability of the thoracic swim leg muscles.

Tube kick exercises are a form of exercise done in the water to form strength in the limbs while improving the movements of the paw-chest swimmer's feet and hands so that with this exercise tube kick is thought to improve the chestpooling skills.

Based on the description above, we can illustrate the following frame of mind:

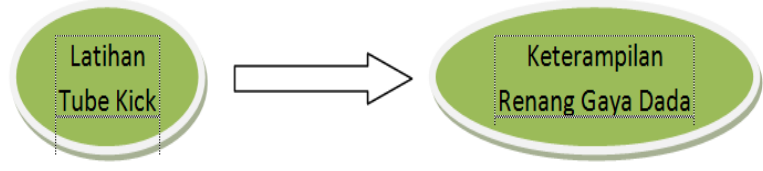

Fig 9. Mind Map Diagram

\section{E. Research Hypothesis}

Based on the background of literature review and frame of mind, it can be formulated research hypothesis as follows: There is the influence of tube kick exercises on the skill of swimming breaststroke of students of Sports Science Coaching Program of 2015/2016.

\section{Research Methodology AND Design}

This research includes experimental research, where there are treatments as independent variables, this treatment is expected to affect the dependent variable. As for the independent variables in this study is the tube kick exercise, while the dependent variable is the chest-style swimming skills. The above method of research is in accordance with that disclosed by [11] that experimental research there is a treatment (treatment), thus experimental research methods can be interpreted as research methods used to find the effect of certain treatment against others.

This research uses the design of One Group PretestPosttest Design, which gives treatment to the independent variable but previously done pretest then treated and ended with Post-test, like the following design:

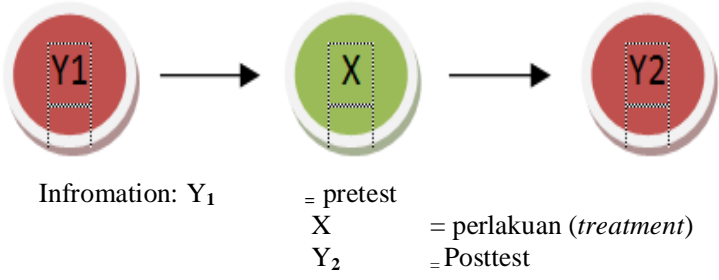

\section{A. Population and sample}

The population of this research is students of Faculty of Sports Science Sports Science Class of 2015/2016, which consists of class A and B. While the sample of this study is a student of Sports Training Course of 2015/2016.

\section{B. Research Instruments}

The instrument used to collect chest pool skill data in this study was a chest pool test while observing the sample using observation sheet guidelines, which contain star technique, arm movement, leg movement, breathing motion, coordination movement, finish motion. The norman chest-style swimming skills as follows:

TABLE 1. SWIMMING SKILL NORMS CHEST STYLE

\begin{tabular}{|c|c|c|}
\hline N0 & Score & Criteria \\
\hline 1 & $17-18$ & Very good \\
\hline 2 & $14-16$ & Good \\
\hline 3 & $11-13$ & Moderate \\
\hline 4 & $8-10$ & Low \\
\hline 5 & $6-7$ & Very Low \\
\hline
\end{tabular}

\section{Data Collection Techniques}

Research data about the skill of breaststroke of coaching sports students of 2015/2016, class A is obtained by conducting the preliminary test and final test to research sample about chest pool skill by:

1. Samples are asked to perform a 50-meter breaststroke pool.

2. Observer observes the chest-pool skills performed by the research sample by matching or checking $(\sqrt{ })$ according to the chest-style skill observation sheet.

3. Calculate how the score obtained by the sample after the skill test breaststroke skill. Each movement corresponding to the observation sheet is rated between 1 (one) to 3 (three). Value 3 because the movement is very precise, the value 2 because of a bit less precise, 1 because it is not right. From the number of scores obtained indicate that the chest-style skill score is owned by each sample. 


\section{Data Analysis Techniques}

Data collected by statistic test using t-test formula, but previously tested normality and homogenizes.

\section{E. Description of Research Data}

Description of research results of the influence of tube kick exercises on chest pool skills Student Sports Coaching Department is as follows:

TABLE 2. DESCRIPTION OF CHEST POOL SKILLS

\begin{tabular}{|c|c|c|c|c|c|c|}
\hline Result & $N$ & Mean & SD & Var & Min & Max \\
\hline Pre Test & 47 & 10.277 & 2.338 & 5.465 & 6 & 14 \\
\hline Post Test & 47 & 14.489 & 2.96 & 8.77 & 9 & 18 \\
\hline
\end{tabular}

\section{1) Preliminary Skills of Group Style Chest Pool}

Description of data is the result obtained from the initial test of chest pool skills in the students of FIK UNJA Prodi Coaching Sports class 2015/2016 class A, based on the results of the initial test obtained an average calculation of 10.277, standard deviation 2.338 , the best skills with score 14 , the lowest skills with a score of 6 and a variance of 5.465. Data distribution of preliminary test results for chest-style swimming skills can be seen in the following frequency distribution table:

TABLE 3. FREQUENCY DISTRIBUTION OF INITIAL TEST DATA

\begin{tabular}{|c|c|c|c|}
\hline No & Interval & Fa & $\mathrm{Fr}$ \\
\hline 1 & 6-7 & 8 & $17 \%$ \\
\hline 2 & $8-10$ & 14 & $30 \%$ \\
\hline 3 & $11-13$ & 24 & $51 \%$ \\
\hline 4 & 14-16 & 1 & $2 \%$ \\
\hline 5 & $17-18$ & 0 & $0 \%$ \\
\hline \multicolumn{2}{|r|}{ Total } & 47 & $100 \%$ \\
\hline
\end{tabular}

Based on the dissemination of data from the tree test results with the total sample 47 obtained 8 samples (17\%) got skill score 6 - 7, 14 samples $(30 \%)$ got skill score $8-10,24$ samples $(51 \%)$ got score skill 11-13, 1-person sample $(2 \%)$ obtains skill score 14-16.

\section{2) End Test of Group Style Breaststroke Skills}

Based on the final test results obtained an average calculation of 14.489 , standard deviation is 2.96 , best skills are 18 , skill lowest is 9 and variance is 8.77 . The distribution of final test result data for basic motion skills can be seen in the following frequency distribution table:

TABLE 4. FREQUENCY DISTRIBUTION OF END TEST DATA

\begin{tabular}{|c|c|c|c|}
\hline No & Interval & $\mathrm{Fa}$ & $\mathrm{Fr}$ \\
\hline 1 & $6-7$ & 0 & $0 \%$ \\
\hline 2 & $8-10$ & 8 & $17 \%$ \\
\hline 3 & $11-13$ & 10 & $21 \%$ \\
\hline 4 & 14-16 & 13 & $28 \%$ \\
\hline 5 & $17-18$ & 16 & $34 \%$ \\
\hline & Total & 47 & $100 \%$ \\
\hline
\end{tabular}

Based on the distribution of data from the pre-test results with the total sample of 47,8 samples $(17 \%)$ obtained a skill score of $8-10,10$ samples $(21 \%)$ obtained a skill score of 1113 , then 13 samples (28\%) obtained skill to score on 14-16, then 16-person samples (34\%) obtained a skill score at 17-18. Data distribution can also be viewed through the following histogram images:

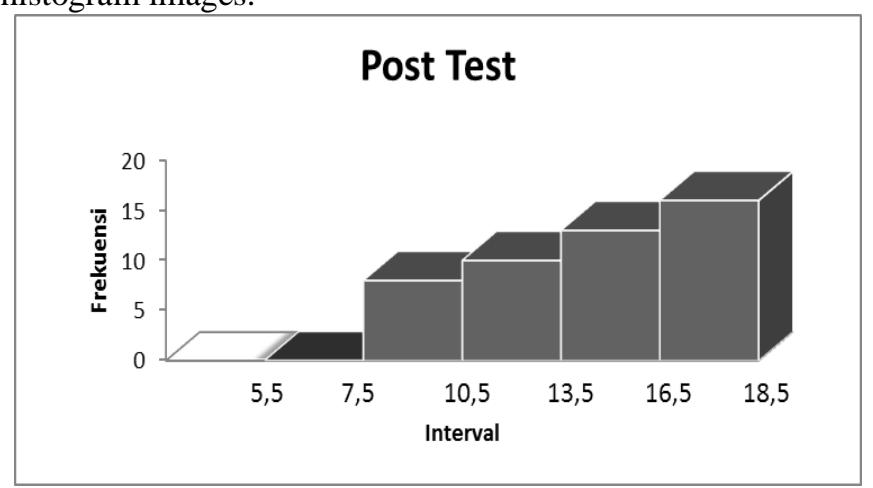

Fig 10. Histogram Results of the Chest Pool Skills Final Test

\section{3) Hypothesis Testing}

Hypothesis test used in this research is by using t-test. Criteria of decision-making with t-test are If $t$ count is greater than $\mathrm{t}$-table or $\mathrm{t}$-count $>\mathrm{t}$-table hence research hypothesis that the influence of tube kick exercise to the skill of breaststroke of a student is accepted.

Based on the results of research and conducted a t-test, obtained as follows:

TABLE 5. HYPOTHESIS RESULTS

\begin{tabular}{|c|c|c|c|c|c|}
\hline No & Test Result & $\mathrm{N}$ & $\mathrm{t}_{\text {hing }}$ & $\begin{array}{c}\mathrm{t}_{\text {table }} \\
\alpha=0.05\end{array}$ & Keterangan \\
\hline 1. & Pre Test & 47 & \multirow{2}{*}{2.867} & 1.98 & Ho acceptable \\
\cline { 1 - 3 } & Post Test & 47 & & Ho acceptable \\
\hline
\end{tabular}

Based on table 7 above, it is known that tcount is bigger than ttable or tcount $=2.867>$ ttable $=1.98$, it means the research hypothesis is accepted so it can be concluded that there is influence of tube kick exercises on the skill of the breast force pool of FIK Jambi University.

\section{DISCUSSION}

Based on the result of the research, the influence of tube kick exercises on the skill of the breaststroke of students of the Training Class of 2015/2016 Class A in the preliminary test with the sample number of 47 people obtained an average of 10.277, standard deviation 2.338, the best skill with score 14 , the lowest skill with a score of 6 and a variance of 5.465.

Normality test results by using the Lillieforts test were obtained at the initial test $=0.1115$ and the final test $=0.1180$ sequentially $<$ Ltable $=0.1292$. So, it can be said the data is normally distributed. While the homogeneity test of variance using F test formula obtained Fcount on preliminary and final test data $=1.606<$ Ftable $=1.69$ at significant level $\alpha=0.05$. with $\mathrm{n}-1=46 \mathrm{dk}$ denominator $(\mathrm{df})=46$ thus the preliminary and final skeletal skills of the breaststroke pool may be derived from a homogeneous population.

Based on the results of hypothesis test obtained tcount $=$ 2.867> ttabel $=1.98$, meaning the research hypothesis accepted so it can be concluded that there is the influence of tube kick exercises on the skill pool style of students FIK UNJA, Departement of Sports Coaching. The above occurs 
because tube kick exercises performed on repeated samples can form strength or limb power, these exercises can form a good and right chest-leg movement and hand movements. High leg muscle strength has better swimming skills than those with low leg muscle ability,

\section{CONCLUSION}

Based on the results of the research, hypnotic testing and data analysis and discussion that has been done before it can be concluded that there is influence of tube kick exercises on the skill of breaststroke students of FIK Unja Prodi Sports Coaching class of 2015/2016 class A, this can be proven by statistical test results by using t-test is obtained tcount $=$ $2.867>$ ttable $=1.98$, with tapaf significance $0.05 \%$.

\section{REFERENCES}

[1] E.W. Moglischo, Swimming Event Faster, California: Mayfield publishing Company, 1993

[2] K. Lutgen and N. Hamilton, Kinesiology Sciantificcbasic of human motion, Dubuge Guilford Brown and Benchmark Publisher, 1997

[3] G.H. James, The Biomechanics of Sports Technique, Englewood Cliffs: Prentice Hall Inc, 1978
[4] I. Saharuddin, Pengaruh Bentuk Latihan dan Kekuatan Otot Tungkai Terhadap Keterampilan Renang Gaya Dada, Studi Eksperiment pada Mahasiswa FIK UNJ, Disertasi, Program Pasca Sarjana Universitas Negeri Jakarta, Jakarta, 2009

[5] D. Heller, Belajar Berenang, Terjemahan, Tim Pionir Jaya, Bandung, 1998

[6] FINA Hand Book, Contitutions and Rules, Swimming, Open Water Swimming, Diving Water Polo, Synhconised Swimming and Doping Control, 2005-2009

[7] http://edukasicenter.blogspot.co.id/2014/12/pengertian-renang-gayadada.html, accessed 12 February 2017.

[8] A. Syarifuddin and Muhadi, Pendidikan Jasmani dan Kesehatan, Departemen Pendidikan dan Kebudayaan Direktorat Jenderal Pendidikan Tinggi, Proyek Pembinaan Tenaga Kependidikan, Jakarta, 1993

[9] https://www.google.co.id/search?q=gerakan+lengan+gaya+dada\&biw=1 $366 \& b i h=623 \&$ source $=1 \mathrm{nms} \&$ tbm $=$ isch $\&$ sa $=X \&$ sqi $=2 \& v e d=0$ ahUKEwj FmJWA74rSAhVCuI8KHQmtBdYQ_AUIByg\#imgrc=b30FUMH9CXS jpM: accessed 12 February 2017.

[10] https://www.google.co.id/search?q=posisi+start+renang+gaya+dada\&es $\mathrm{pv}=2 \& \mathrm{biw}=1366 \& \mathrm{bih}=662 \&$ source $=1 \mathrm{nms} \& \mathrm{tbm}=\mathrm{i}$ sch $\& \mathrm{sa}=\mathrm{X} \& \mathrm{ved}=0 \mathrm{ah}$ UKEwi9oNO2oI3SAhVBt48KHV_MDqgQ_AUIBygC\#imgdii=6M5AI q_8u-69_M:\&imgrc=1SmCBEQliJiakM (accessed 13 Pebruari 2017).

[11] Sugiyono, Metode Penelitian Pendididkan Kulitatif, Kuantitatif dan R \& $\mathrm{D}$, Alfabeta, Bandung, 2008 